\title{
Organic fruit production in Switzerland: Research and development to resolve cultural, management, and marketing problems
}

\author{
Franco P. Weibel
}

Abstract. The area devoted to organic table fruit production in Switzerland remained virtually unchanged from the 1930s to the mid-1980s. However, during the last decade there has been a fivefold increase in the production area, approaching a total of 340 ha in 2000 (4.8\% of the total area of table fruit production). Factors contributing to this dramatic increase include (1) new and effective non-chemical methods for pest and disease control, (2) improved management and production techniques from research and extension programs, (3) increased marketing of organic produce by supermarkets due to consumer demand, and (4) change in Swiss government policy that began to subsidize ecological performance rather than farm production. A 1994 poll of consumer demand indicated that 3 to $5 \%$ of the total apples marketed in Switzerland was organically grown, and projected a total market share of $10 \%$ in the near future. Despite this, conventional fruit growers are hesitant to convert to organic production methods because of certain risks involving (1) selection of varieties, (2) pest and disease control, (3) crop hectarage controls, (4) weed control, and (5) tree nutrition. Research and development programs are attempting to deal with these problems, to reduce the level of risk with organic production. Nevertheless, ecological considerations to optimize fruit production are strongly dictated by market conditions and consumer demand. Finally, the development of a stable organic fruit production sector will require that retailers and supermarkets make certain concessions for marketing organic fruit.

Key words: agricultural policy, apples, fruit crops, organic farming, quality labeling, quality standards

\section{Introduction}

The Research Institute of Organic Agriculture (in German, Forschungsinstitut für biologischen Landbau) (FiBL, 2000) was established as a private foundation in 1974 near Basel, Switzerland, by organic farmers, scientists, politicians, and industry representatives. Its mission is to conduct applied agronomic and economic research on organic farming methods, and to disseminate new findings to farmers. Currently the Institute employs about 85 individuals affiliated with 4 departments, including 3 research departments and 1 providing advisory and training services.

Although a private foundation, $\mathrm{FiBL}$ is funded by the federal government (38\%), the Swiss cantons, and private institutions, as well as by revenues from provision of planning and advisory services. Currently, its annual revenues are 3.7 million Euros for research and 1.7 million Euros for intraining and extension work. The research activities of FiBL are organized in the following departments and groups:

- Department of Soil and Plants (four groups): Soil Ecology, Crop Production and Crop Quality, Plant Protection, and BioGene

- Department of Livestock (three groups): Animal Health, Animal Husbandry, and Animal Breeding

- Department of Landscape and Econom-

F.P. Weibel is Research Scientist, Research Institute of Organic Agriculture, Ackerstrasse, 5070 Frick, Switzerland (franco.weibel@fibl.ch). 
ics (two groups): Landscape and Biodiversity, and Economics and Standards

- Branch in Berlin, Germany

\section{Historical Aspects of Organic Fruit Production in Switzerland}

Interest in organic farming, and particularly, organic fruit production began in the 1920 s and 1930s when there was little difference between conventional and organic production methods. With the proliferation and availability of chemical fertilizers and pesticides, conventional fruit growing expanded markedly for reasons of yield reliability, improved fruit quality, and production intensification, which led to the development of fruit farms with a high level of specialization. Meanwhile, the cultural methods and production levels for organic fruit production changed very little, and consequently, most of the funding for private and government research and extension programs was directed toward the improvement of conventional fruit production systems. Moreover, because of inherently low-yielding orchards, most organic growers were reluctant to undertake unknown risks involved with changing to new organic cultural and management methods. This historical scenario led to a dichotomy between conventional and organic fruit production in Switzerland, which still exists today, particularly with regard to such factors as production intensity, professional competence, fruit quality standards, private and government support of research, subsidies, and marketing conditions.

\section{Evidence of change in recent years}

Despite the dichotomy between organic and conventional fruit growing, three areas of change occurred during the early to mid-1990s that encouraged and strengthened the future of organic fruit production in Switzerland. These are briefly discussed as follows.

More effective products and methods for controlling pests and diseases. In the past decade, research conducted mainly by the private sector has yielded a number of new, non-chemical products and methods for controlling pests and diseases, which previously were major constraints to or- ganic fruit production. Some of these key problems and current control measures for apple (Malus sp.) in particular are:

- Control of apple coddling moth (Adoxophies orana) with granulosis virus and pheromone mating disruption;

- Control of rosy apple aphid (Dysaphis plantaginea) with pyrethrum-rotenone; formulations, and neem tree (Azadirachta indica) extracts;

- Control of saw fly (Hoplocampa testudinea) and other pests with quassia bark extracts;

- Control of apple scab (Venturia inaequalis) with clay powder in combination with copper and sulfur compounds;

- Control of sooty blotch (Gloeodes pomigena) and fly speck (Schizothyrium pomi) with coconut soap;

- Development of a rope machine for the mechanical crop load regulation in apple production (blossom thinning) suited for slender spindle trees; and

- Improved control of weeds in the interrow areas with more effective soil tillers.

These effective biocontrol and cultural methods, used in conjunction with new disease-resistant varieties, have greatly increased yields and fruit quality, and enabled organic growers to expand and intensify their fruit production operations. The resolution of such key problems through cultural and management techniques also encouraged some innovative conventional growers to seriously consider conversion to organic production.

Market development incentives. The strongest incentive advancing the development of organic fruit production in Switzerland in recent years is attributed to major supermarket chains requesting reliable sources and supplies of organically grown fruit, especially apples. Coop, the second largest supermarket chain in Switzerland, began selling organic products, including fruit, in 1994. To increase the availability of organically grown fruit, Coop provided considerable support for an apple research project of FiBL. This development was driven by increased demand for organic fruit, in part because of consumer desire to support an environmentally friendly agriculture, and because of a perception by many that organic food is more "natural" and imparts health benefits not attain- able with the consumption of conventionally grown foods.

These incentives were the beginning of a fundamental change in organic fruit production in Switzerland. It involved a major shift away from traditional nichetype production to a more highly specialized and professional system employing the latest cultural and management methods and technologies to achieve consistently high fruit yields and acceptable product quality to attract supermarket customers. Consequently, Bio Suisse, the almost monopolistic label keeper of organic farming in Switzerland, intensified its activities to support the marketing of organic fruit. Bio Suisse is the umbrella organization of organic growers, retailers, and wholesalers and identifies itself by the "flower-bud" label. Bio Suisse estimated that, in $1999,35 \%$ of fresh organic fruit was retailed to consumers through supermarkets, $40 \%$ by small shops, and $25 \%$ by direct sales on the farm (Bio Suisse representative, personal communication, 1999).

The production and marketing development of organic cherries (Prunus spp.), plums (Prunus spp.), apricots (Prunus armeniaca), and berries mimics that for apples, in some respects, although their total areas of production are much less (Fig. 1). At present, production and marketing of these fruits are in the build-up phase and benefiting from the pioneering experiences obtained with organic apples.

Organic-friendly farm policies. In 1996, the Swiss government drastically revised its support policies for agriculture, mainly to resolve the problems of overproduction and to enhance environmental protection. Consequently, subsidies were terminated for farm commodities but maintained for a farm's ecological performance. A feature of this new policy is that to receive compensation, $7 \%$ of the total farm area must comply with ecological standards established for biodiversity and wildlife habitats. There are now 15 different types of ecological compensation for farms under the new Swiss government farm program. Thus, not surprisingly, farms meeting the standards of organic production are receiving the highest subsidies. However, despite the very costly investments associated with fruit production, this ecological compensation has not 
been a decisive factor in causing conventional fruit growers to convert to organic production. Nevertheless, this ecological/ environmental emphasis under the new Swiss government farm support program is viewed as a sign of official acceptance and approval of organic methods of farming. Finally, this new program has given organic farmers a special measure of dignity and respect, while the Swiss public has become more "organic friendly."

In 1998 Switzerland established the Federal Ordinance on Organic Agriculture (www.admin.ch/ch/d/sr/c910_18.html).

This ordinance is compatible with the EURegulation on Organic Farming 2092/91 (European Commission, 1991), but also contains established elements of the Bio Suisse regulations (Bio Suisse, 2000). All regulations named correspond with those of the International Federation of Organic Agriculture Movements (IFOAM), an international umbrella organization that supports the organic farming movement (IFOAM, 2000).

Dissemination of research results and technology transfer. The dissemination of research results from public and private organizations and the farmer-tofarmer exchange of information on organic methods and management skills are vital to the agronomic and economic success of organic fruit growers. The fruit group of FiBL has published a series of technical leaflets for updating grower education on organic fruit farming (Häseli and Weibel, 1996). To ensure the presence of a strong and continuing outreach activity, the Swiss organic fruit growers and the fruit group at FiBL in 1994 jointly established seven regional organic fruit grower groups to disseminate research results and practical information, and improve professional training. Each grower group organizes and convenes four to eight meetings annually that include such activities as (1) practical field demonstrations of organic methods and technologies, (2) presentation and discussion of new research results, and (3) sharing of experiences and information among growers.

\section{Quality Standards for Grading Organically Grown Fruit, Especially Apples}

Switzerland has adopted special na-

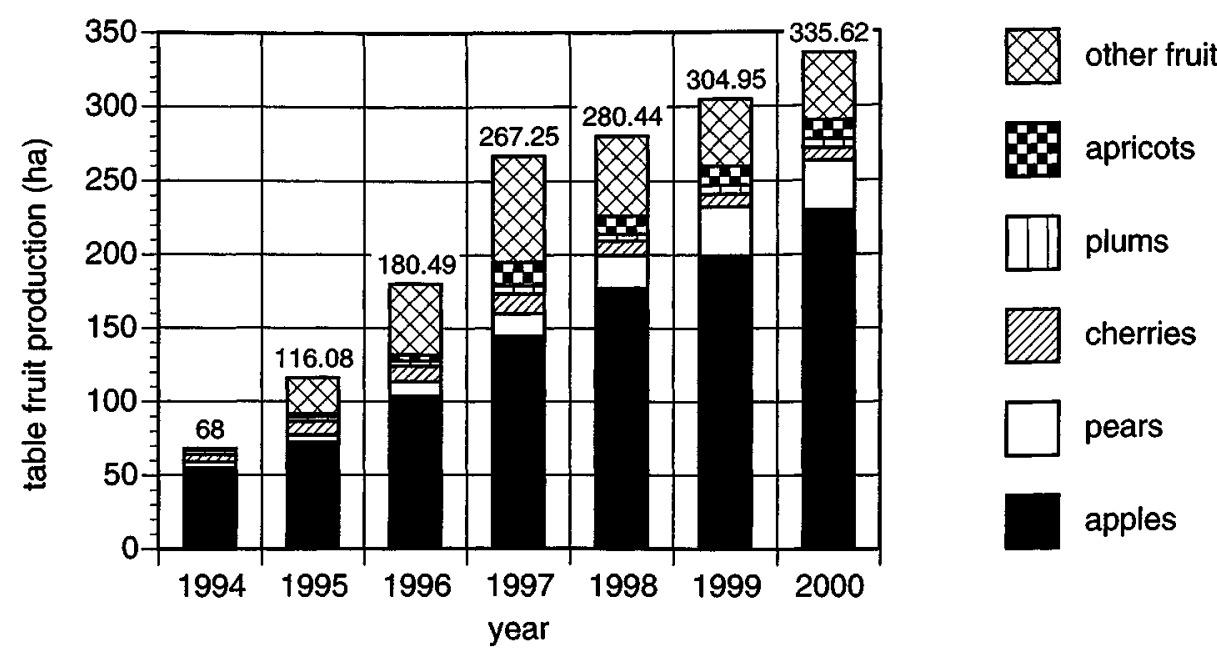

Figure 1. Evolution of production area of organic table fruit in Switzerland since 1994 (1994 and 2000 approximations, 1995-1999 data of FIBL certification service).

tional quality standards to govern the grading of organic fruit. For example, some undersized apples that would be graded as class II fruit if conventionally grown can be graded as class I fruit if they meet coloration standards of class I fruit. Moreover, apples having small cosmetic defects, such as scab spots less than $3 \mathrm{~mm}$ in diameter and less than $1 \mathrm{~cm}^{2}$ in total area, can be graded as class I fruit. If cosmetic standards were to be applied uniformly in Switzerland, i.e., to both organic and conventional fruit, the organic grower would likely need to intensify crop protection measures to avoid blemishes. Some would argue that such action would detract from the image and intent of organic agriculture, and thus penalize the grower and endanger the credibility of the "brand" or "label."

In the United States, quality standards (e.g., size, color, cosmetics) for apples are exactly the same regardless of whether the fruit is grown organically or conventionally [editor's note]. However, this U.S. standard, in the author's opinion, would lead to exaggerated cosmetic plant protection and fertilization practices that are not compatible with the original goals of organic agriculture. Fortunately, in Switzerland we are still able to defend reasonable and "truly organic" quality standards.

Quality and grading standards for organic fruit in Switzerland are established through Bio Suisse. Starting in 1994, the Fruit Expert Group of Bio Suisse (consisting of the chairpersons for each re- gional grower group, organic trade representatives, and an official of FiBL) has met annually with the organic marketing partners to establish fruit quality and grading standards, and recommend market prices for the coming season. This annual "round table" has helped to avoid disruptive price and quality conflicts. It has also helped to persuade conventional retailers that certain marketing accommodations for organic fruit are necessary to preserve the image and intent of ecological production methods.

To preserve the organic-friendly atmosphere for growers in the future, it was considered essential to inform consumers of their role in sustainable production. An example of this was the successful implementation of a new marketing concept developed by FiBL to introduce "unknown" scab-resistant (or -tolerant) apple varieties to consumers through Coop supermarkets. This educative marketing strategy informs consumers mainly on the taste of the "unknown" variety receiving major emphasis on the packing labels, but with the variety name included almost as an afterthought (e.g., fruit color is not described because consumers can see and judge it directly, which is not the case with taste) (Weibel and Grab, 2000). On occasion, consumers receive an information leaflet explaining the color-guided taste groups, specific details of organic fruit growing, and the importance of disease-resistant or diseasetolerant varieties. For growers, the tasteguided marketing system allows more

Volume 16, Number 4, 2001 
flexibility in selecting and evaluating new varieties from breeding programs that focus on increased pest and disease resistance, and improved fruit quality.

\section{The Transition from Conventional to Organic Fruit Production}

A consequence of the improved climate for producing organic apples has been that some large and specialized conventional fruit farms have, since 1994, converted to organic production. Today, these "converted" farms are producing a major portion of the organic fruit in Switzerland. While these farms are currently selecting scab-tolerant and -resistant apple varieties, the main organic varieties are still Golden Delicious, Maigold, Idared, and Boskoop.

Currently, the production area for organic table fruit is approximately 340 ha (approximately 230 ha in apples, see Fig. 1), a fivefold increase since the early 1990s. Presently, of the total Swiss apple production for fresh consumption, 3 to $5 \%$ consists of organic fruit, a level that does not meet market demand. It is noteworthy that medium-quality organic apples are difficult to sell. Meanwhile, some organic growers have begun to export their highquality "mountain" apples to other European Community countries, where they compete effectively for higher market prices. It is estimated that the Swiss market potential for organic apples will eventually range from 10 to $20 \%$ of the total Swiss fresh apple production (Schmid et al., 1995).

The proportion of organic apples and pears for processing, mainly as juice, is approximately $8 \%$ of Swiss production. These fruits are grown extensively on high-stem (sometimes referred to as standard) trees that are costly to maintain, yet serve to increase the plant and animal biodiversity of the traditional landscape. In sharp contrast with conventional processing fruit, the organic market is not yet saturated and farmgate prices for organic fruit are almost double those for conventional fruit.

The market potential for organic apples could be expanded by (1) increasing the volume of the fruit in supermarkets, (2) growing varieties that can be stored longterm, and (3) educating consumers about the quality features of organic fruit. A comparative study (Weibel et al., 2000) showed that organically grown apples were of higher quality than conventionally grown apples with respect to parameters that relate to health and taste (e.g., taste score, sugar-acidity-firmness index, nutritional fiber content, phenolic compounds content, and "vitality index," the latter according to picture-grading methods for holistic quality assessment).

A number of the large fruit farms experienced serious problems following their conversion from conventional to organic apple production. During the first 4 years, most farms were confronted with problems that they had not encountered previously with conventional management, or ones that were much more difficult to resolve than had been expected (e.g., apple scab, sooty blotch, woolly apple aphid [Eriosma lanigerum Hausm.], additional hand labor for fruit thinning and tilling around trees, and additional time for establishing market contracts). Many growers found that merely replacing synthetic agrichemicals (chemical fertilizers and pesticides) with organic products did not adequately supply nutrients or control pests and diseases. Through contacts with experienced organic farmers, these "new" organic farmers soon learned the importance of supplemental indirect measures such as (1) proper site selection for new plantings, (2) moderate planting densities, (3) selection of robust varieties, (4) promoting orchard biodiversity, and (5) maintaining good soil quality and fertility. After conversion to organic fruit production, farmers are often frustrated when suddenly realizing that they have only protective measures, and no curative-systemic methods at their disposal. Successful organic fruit production depends quite heavily on the presence of natural predators and antagonists to control pests. If the populations of these beneficial insects decline due to man-made or natural events, epidemics of wooly apple aphid or red spider mite (Panonychus ulmi Koch) may occur. Even so, the populations of natural predators and antagonists tend to recover rapidly in most organic systems and the protective potential is soon reestablished. Nevertheless, the short-term damage would likely be considerably more severe than it would have been with conventional practices.
Yield reductions of 10 to $15 \%$ for organically grown applies can usually be offset by a higher proportion of marketable fruit as a consequence of less stringent grading standards.

The farmgate prices to retailers for organic fruit range from 15 to $130 \%$ above market prices for conventionally grown fruit. Generally, a farmgate price of $30 \%$ above market is necessary to cover the higher yield risk and production costs of organic fruit production. If retailers attempt to use the same percentage markup in reselling the fruit (e.g., apples), it could easily double the market price to consumers, which they may refuse to pay. Consequently, the fruit group of Bio Suisse has recommended that retailers resell organic fruit with the same absolute margin used for conventional fruit. Thus, the consumer price for organic fruit is seldom 50 to $70 \%$ higher than that for conventionally grown fruit.

\section{Summary and Conclusions}

Improvements in pest and disease management, an increase in market demand, especially by supermarkets, and the ecological orientation in Swiss agricultural policy have led to a remarkable increase in organic apple production in Switzerland. Important elements of the success story arise from innovative activities occurring at all levels of the product chain, including (1) research for production improvement, (2) intensification of extension education for growers, (3) concepts for disseminating consumer information, and (4) market introduction of scab-resistant varieties. The "coming-out" phase from the niche to the supermarket holds certain risks for organic growers; e.g., if the quality demand, especially for appearance, is the same as for conventional fruit, growers may be forced to apply organic pesticides and fertilizers just for cosmetic purposes, which would otherwise be unnecessary. In the long run this would harm the image of and market opportunities for organic agriculture. It is of highest importance to maintain strict standards for organic production, and reasonable, ecologically oriented quality goals, in order to maintain a healthy and credible organic agriculture for the future. In Switzerland this calls for intensifying research in the production of 
organic apples (including variety testing, control of pests and diseases, crop hectarage controls, weed control, and tree nutrition), along with new efforts to expand production and markets for cherries, plums, apricots, and berries. Some activities to achieve these goals have already begun. The gains made by the organic apple industry in expanding production and marketing activities should help to accomplish these ambitious goals more efficiently.

\section{References}

1. Bio Suisse. 2000. Standards for the Production, Processing and Marketing of Produce from Organic (Biological Ecological) Farming [English transl.]. Rev. 1 June. Basel, Switzerland. Web site http://www.biosuisse.ch/html/e_bibliothek_1.html.
2. European Commission. 1991. Council Regulation (EEC) No. 2092/91 of 24 June 1991 on Organic Production of Agricultural Products and Indications Referring Thereto on Agricultural Products and Foodstuffs. Document 3091R2092. Web site http://europa.eu.int/eur-lex/en/lif/dat/ 1991/en-391R2092.html.

3. FiBL. 2000. Home page. Forschungsinstitut für biologischen Landbau, Frick, Switzerland. Web site http://www.fibl.ch.

4. Häseli, A., and F. Weibel. 1996. Pest and disease management in organic apple growing (in German: Krankheits- und Schädlingsregulierung im biologischen Apfelanbau). 2nd ed. Technical leaflet. Forschungsinstitut für biologischen Landbau, Frick, Switzerland.

5. IFOAM. 2000. International Federation of Organic Agriculture Movements, TholeyTheley, Germany. Web site http://www.i foam.org.
6. Schmid, O., Ch. Binggeli, and S. Lehmann. 1995. Bioobstmarkt Schweiz-Analyse und perspektiven. Betriebswirtschaft im biologischen Landbau. Ökologie und Landbau 23:191-197.

7. Weibel, F., and F. Grab. 2000. Sustainable production needs sustainable marketing: Evaluation of a new marketing concept to introduce organically grown scab (Venturia inaequalis)-resistant apple varieties at the Swiss supermarket retailer Coop. Proc. 13th International Federation of Organic Agriculture Movements (IFOAM) Scientific Conference, 28-31 August 2000, Basel, Switzerland. Tholey-Theley, Germany. p. 255-258.

8. Weibel, F.P., R. Bickel, S. Leuthold, and T. Alföldi. 2000. Are organically grown apples tastier and healthier? A comparative field study using conventional and alternative methods to measure fruit quality. Acta Hort. 517:417-427.

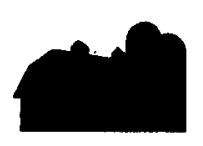

\section{BOOK REVIEW}

Economic Performance of Organic Farms in Europe. Frank Offermann and Hiltrud Nieberg. 2000. Organic Farming in Europe: Economics and Policy, Volume 5. University of Hohenheim, Department of Farm Economics, Stuttgart, Germany. xviii + 198 p. 24 Euro, ISBN 3-93340304-9, softcover.

As U.S. efforts to develop national organic standards began to stall in the early 1990s, Europe pushed ahead with farreaching programs and policies to encourage the adoption of organic farming. Europe now has a very fast-growing organic farming sector with high levels of market demand as well as direct financial support-at levels that vary widely across countries and commodities-and is poised to commit even more resources to encourage adoption.

The authors of Economic Performance of Organic Farms in Europe have used data and research from a variety of studies to provide an astonishingly detailed synthesis of the profitability of organic farming in 18 countries in Europe during the last decade. Labor use, yields, prices, and support payments on organic farms are compared across the spectrum of commodities and countries, and a range of thorny issues-such as the risk of organic price premiums dropping with an expansion of supply-are tackled. The authors conclude that profits on organic farms were on average comparable to those on conventional farms during the 1990 s, and that the relative competitiveness of organic systems is likely to increase as a result of the current European policy agenda.

This volume contains rigorous and meticulous economic analysis, and will therefore be valuable for economists exploring organic farming systems. It is also worthwhile reading for a much wider audience. Research scientists who are studying the agronomic and ecological aspects of organic farming will gain a broader understanding of the range of economic questions that should be asked at the outset of an organic farming systems project. Educators and information specialists who provide technical outreach to the organic farming community will also find valuable reference material in this study. In addition, U.S. policymakers will find useful the analysis of the combined impact of multiple policies on the organic farm sector, as they grapple with similar questions on income support, agri-environmental payments, and other emerging features of U.S. farm policy.

This report analyzes the economic performance of the organic farm sector in the 15 member states of the European Union, as well as 3 non-EU countries (Norway, Switzerland, and Czech Republic). Contributors include economists and policy specialists from all 18 countries that are reviewed. The analysis is based on data from published studies, and unpublished results from ongoing research projects and farm accounting reports. The observations are mostly for the 1990s. The book opens with a chapter on the methods used for the analysis (Ch. 2), followed by a description of the resources and production structure of organic farms in Europe (Ch. 3), an overall analysis of organic yields, prices, and costs (Ch. 4), and a detailed look at the organic farming sector in each country (Ch. 5). The impacts of Common Agriculture Policy (CAP) reform on organic farming in Europe are discussed in Chapter 6 , followed by conclusions. The book includes an extensive bibliography 